\title{
ELT Preservice Teachers' Conceptualization of Teaching Practice: A Metaphor Analysis of the Dynamics of Teaching Practice
}

\author{
İlknur Yüksel ${ }^{1}$ \\ ${ }^{1}$ Department of English Language Teaching, Education Faculty, Eskişehir Osmangazi University, Turkey \\ Correspondence: İlknur Yüksel, Eskişehir Osmangazi University, Eskişehir, Turkey. E-mail: \\ ilknuryuksel.elt@gmail.com \\ Received: July 25, 2019 \\ Accepted: August 20, 2019 \\ Online Published: August 22, 2019 \\ doi:10.5430/ijhe.v8n4p254 \\ URL: https://doi.org/10.5430/ijhe.v8n4p254
}

\begin{abstract}
Different from other studies on the metaphor analysis of pre-service teachers and their cognition on teaching, the present study adopted a larger perspective and investigated their conceptualization of the dynamics of the practicum, namely teaching practice, mentors, supervisor, students, lesson plan and materials. 35 pre-service teachers were asked to complete a metaphor elicitation task on six dynamics of teaching practice. Applying the conceptual metaphor analysis, 189 metaphors were determined and categorized for each concept. The overall results indicated that the pre-service teachers could conceptualize their beliefs on teaching practice dynamics referring to their experience. In line with their beliefs and attitudes, they chose the metaphors with positive or negative connotations. Some participants were positive about the practicum while some described the practicum with negative affective metaphors under the categories of pitfall and vagueness. Besides, the participants mostly used cognitive metaphors describing the authority of mentors and supervisors. In addition to the affective affirmative metaphors on the students, the participants described the students as out-of-control, referring to the classroom management problems. The contributions of lesson plan and material use were mostly appreciated with positive metaphors but the metaphors categorized under uncertainty and redundancy called for the participants' need for supervision and support. The results of the study revealed that the pre-service teachers' beliefs and performances were apt to be influenced with what they experience during the practicum. Through an understanding of pre-service teachers' conceptualization regarding their experience, training and applications could be improved.
\end{abstract}

Keywords: metaphor, practicum, pre-service teachers' beliefs, mentors, supervisor, students

\section{Introduction}

Teacher cognition is the key to unlock the teachers' professional practice, which is fundamental to ensure the quality of education. In particular, teachers' cognition refers to the unobservable cognitive dimension of teaching; "what teachers know, believe, and think and the relationships of these mental constructs to what teachers do in the language classroom" (Borg 2003, 81). To explore the complexity of cognition, teachers' beliefs have been mostly focused in many studies with different research designs so far (e.g. Pajares, 1992; Peacock, 2001; Othman \& Kiely, 2016). It has been widely agreed that the beliefs that teacher candidates bring with them into their teacher education programs relate strongly to the form of teaching they have experienced as language learners (Richardson, 2003) and hence these tacit, grounded pre-existing beliefs influence their instructional practices as language teachers (Borg, 2005).

Throughout teacher education programs, teacher candidates are exposed to different theoretical knowledge on how to teach, meanwhile they observe many different teaching practices of different teachers and they internalize many of these values, beliefs and practices (Lortie, 1975; Borg, 2003). After this schooling experience, they face with teaching practice and they revise and sometimes reconceptualize their beliefs as they experience (Mattheoudakis, 2007; Yuan \& Lee, 2014). The first and important phase of teaching experience is practicum, as an induction into the profession both to improve teachers' teaching skills and to extend the body of knowledge on effective teaching practices (Collinson et al, 2009). The practicum is the time when theory meets practice, in a way that pre-service teachers have the opportunities to develop lesson plans, implement different teaching methods and techniques and practice classroom management (Jonston, 1994; Peacock, 2001), besides, they could reconsider their beliefs about teaching and learning as they encounter the real classroom environment (Debreli, 2016).

Although it is widely accepted that the practicum has potential effects on the pre-service teachers' perceptions, 
attitudes, awareness and beliefs (Suárez Florez \& Basto Basto, 2017; Yuan \& Lee,2014) there are still controversial findings of the studies on the change in beliefs through practicum (Mattheoudakis, 2007; Yuan \& Lee, 2014; Cabaroglu \& Roberts, 2000), For instance, Mattheoudakis, (2007) indicated that the pre-service teachers tested their theoretical and practical knowledge and became more aware of their personal beliefs as they taught in real classrooms during practicum. Consistent with this study, Debreli (2016) also found out the incremental changes in belief system as the pre-service teachers taught throughout the program. These studies revealed how teaching in real contexts could change pre-service teachers' beliefs. To explain the changes in the belief systems, different research designs have been conducted; Yuan and Lee (2014) and Cabaroglu and Roberts (2000) defined belief change process categories such as elaboration, disagreement, confirmation etc. to analyze the quantitative and qualitative data and they put forth teaching practice could cause certain changes and development in the pre-service teachers' beliefs. Yet, the practicum and its reflections on pre-service teachers' beliefs still remained unexplored.

To unveil the cognition of pre-service teachers that filter and guide their teaching practice, there is a need to research into cognitive models of their thinking, in addition to surveys, interviews, and observations as the most widely employed data collection techniques in teacher cognition studies. In that point, metaphor studies have come to the fore to portray the teachers' way of thinking and beliefs. Clandinin (1986) defined metaphors as the indications of the way teachers think about teaching and also guide the way they act in the classroom. In the same vein, Wan, Low and $\mathrm{Li}$ (2011) suggested that metaphors can function as a powerful tool in gaining insight into students' and teachers' cognition. In fact, the growing body of literature revealed that teachers often use metaphorical expressions to talk about their beliefs and practices (Tobin, 1990; Seferoglu et al 2009; Casebeer, 2015). Thus, metaphors can be used as a key to unlock the pre-service teachers' cognition, which is of great importance not only for teacher education program but also throughout their teaching career (Borg, 2003).

As the first step to teaching profession, the process of practicum can be examined through metaphors in order to gain better insights into how the pre-service teachers conceptualize their beliefs as they experience teaching during the practicum. Although there are some studies on the investigation of practicum process through metaphor analysis (Seferoglu, et al, 2009; Nagamine, 2012; Casebeer, 2015), they were mostly constrained to the pre-service teachers' beliefs about teaching and learning and being a teacher. However, to grasp the practicum process better, pre-service teachers' beliefs regarding all dynamics of practicum, that is; all components of the process including lesson planning, teaching practice, students, mentors, supervisors so far, should be examined. Addressing to this need the present study is conducted to examine the ELT pre-service teachers' beliefs regarding all dynamics of teaching practice through metaphor analysis. It is aimed to provide a comprehensive insight into practicum process unveiling the pre-service teachers' beliefs about all dynamics and to discuss their conceptualizations. Through an understanding of pre-service teachers' conceptualization, pre-service teachers' beliefs would be surfaced and acknowledged as suggested by Seferoglu et al (2009) and this would guide pre-service teachers to review and adapt their beliefs and practices, besides it would shed light on the practicum process covering all dynamics from the pre-service teachers' lenses.

\subsection{Metaphor Studies on Pre-service Teachers' Cognition}

There is a recent shift in the research on teachers' cognition from quantitative designs to qualitative designs, particularly metaphor analysis has become prominent to uncover the teachers' belief system as the link with what teacher think and expressed through metaphoric language and the actions was suggested in different studies (Tobin, 1990; McGrath, 2006; Saban, 2010; Seferoglu et al, 2009; İnceçay, 2015). Basically, metaphors can be defined as the windows into how human beings conceptualize the world and the reality by express one entity in terms of another entity (Lakoff and Johnson, 1980). Metaphors shape our perceptions and thoughts, and they may influence the actions we take in the real world (Collins and Green, 1990). Therefore, the metaphors that teachers use regarding teaching and learning processes give hints about their underlying beliefs and attitudes behind their practices. As Carter (1990) put forth metaphors are not just reflectors of the beliefs but also influence directly or indirectly classroom performance of the teachers. In other words, metaphors can indicate the way teachers think about teaching and thus, direct the way they teach (Kramsch, 2003; Saban, 2006; Karagöz, Şükür \& Filiz, 2018).

In this context, the metaphors are considered as beneficial and powerful tool to uncover pre-service teachers' cognition. The growing body of the literature on the metaphor analysis of the pre-service teachers has indicated that metaphor use of the pre-service teachers could bring out the underlying beliefs regarding professional identity (Nagamine, 2012) learning and teaching (Seferoglu et al, 2009), encourage reflection (Farrell, 2006), reveal the contradictions and then foster the change in beliefs and practice (Tobin, 1990, Cortazzi \& Jin, 1999). For instance, Tobin (1990) stated that metaphors of teaching and learning could inform about teacher change processes. By 
conceptualizing teachers' beliefs and roles through the metaphors they use, and then introducing more appropriate metaphors, teacher change can be implemented.

In the growing body of the literature, different metaphor studies have been conducted in various contexts with different research design; Oxford, Tomlinson, Barcelos, Harrington, Lavine, Saleh, and Longhini's (1998) study was one of the pioneering research proposing the categories for the conceptual metaphors of teacher, which are Teacher as Nurturer or Teacher as Competitor into four major viewpoints: Social Order, Cultural Transmission, Learner-Centered Growth, and Social Reform. When the relationship between these categorized metaphors and language teaching practices was examined it was found that metaphors raised the pre-service teachers' awareness and in turn, they changed actual teaching practice and classroom environment. In the same vein, Farrell (2006) studied and categorized the conceptual metaphors of teacher into three types as Social Order, Cultural transmission and Learner-centered growth. When the change of metaphor uses through the practicum process was examined, it was detected that the pre-service teachers tended to confirm the information in line with their beliefs but they denied the contradictory ones. Farrell (2006) emphasized how the metaphors could trigger reflection on the beliefs and practices. Additionally, Nagamine (2012) conducted a case study to examine the effect of practicum on the pre-service teachers' professional identity through metaphor analysis. The study explained how the participants' firm beliefs tend to change as a result of supervised practicum. According to Lin, et al.'s (2012) research, the metaphor could provide a framework in which the participants "solidify their views of teaching and learning". The evolution of metaphor uses before and after practicum was also ascertained in Şimşek's study (2014) and Kavanoz's cross-sectional study involving sophormore, junior and senior students with the results of gradual improvement in the teacher metaphors throughout the years, particularly after the practicum.

Although the effect of the practicum on the pre-service teachers' beliefs was widely agreed in many metaphor analysis researches (e.g. Nagamine, 2012; Hasim, Mohtar \& Zakaria, 2013; Kavanoz, 2016; Karagöz et al, 2018), the research focus of those studies were mostly limited to the conceptual metaphors of teacher, teaching and learning. For instance, Karagöz et al (2018) conducted a recent metaphor study with pre-service teachers on being an EFL teacher. The results indicated that most of the participants adopted traditional roles of a teacher as a provider of information. Although the rationale of studying with senior students was implied as the practicum, as they experienced being a teacher during the school practices, the components of practicum that might influence the participants' beliefs as reflected in their metaphor uses were ignored. Form a larger larger and different perspective, Kavanoz (2016) revealed how pre-service teachers' thinking about teaching and learning differed throughout their teacher education. As they expanded pedogogical knowledge and experience teaching practice through practicum, they conceptualized teaching and learning within learner-centered paradigm more than the teacher-centered paradigm. This transformation in the participants' conceptualization was interpreted as the construction and indeed reconstruction of teacher identity. In that point, Kavanoz (2016) underlined the importance of practicum to shape the pre-service teachers' beliefs and teacher identities. Yet, the other factors consisting the practicum process was not again investigated so the transformation process could not be explained in a comprehensive way.

Eren and Tekinarslan (2013) was one of the rare studies adopting a varying and larger perspective on the metaphor analysis of beliefs in relation with the practicum. In their study, 389 pre-service teachers' metaphors regarding the concept of teacher, teaching, learning, instructional material, and evaluation were analyzed. They discussed how the practicum and education contexts shaped their beliefs over cognitive and affective metaphors. As Eren and Tekinarslan (2013) emphasized, to unveil the pre-service teachers' beliefs, cognition regarding the teaching and learning processes, different dynamics should be taken into account so that the related and effective factors and consequences of their beliefs could be discussed comprehensively.

Of these dynamics, there are students, supervisors, mentors with whom the pre-service teachers interact during the practicum and these interactions lead some kind of transformation in their belief systems. In the same way, there are some requirements such as lesson plan and material use, which are important for their teaching performances. Their experience with such requirements could also shape their belief system. Considering all, to explore the pre-service teachers' conceptualizations during teaching practice, all these dynamics should be taken into account to gain a comprehensive insight. Although the practicum and pre-service teachers' beliefs have been a research focus of many studies so far (e.g. Kavanoz, 2016; Şimşek, 2014; Eren \&Tekinarslan, 2013; Nagamine, 2012; Borg, 2003; Cabaroglu \& Roberts, 2000), the pre-service teachers' conceptualization of the teaching practice referring to its main dynamics has been neglected. Addressing to this gap, the present study aimed to investigate the pre-service teachers' conceptualization about the teaching practice in terms of teaching practice/practicum; supervisor, mentor, students, lesson plans, material as the dynamics of teaching process. Through this study, the pre-service teachers' tacit beliefs about the practicum process, supervisors, mentors, students and other requirements of the process would be revealed 
and it could provide an opportunity to evaluate the process and teacher education programs. At the same time, this metaphor study could be a reflection tool for the pre-service teachers at the onset of their teaching career.

\section{Method}

In this study, a metaphor analysis was conducted on conceptual metaphor theory (Cameron \& Low, 1999). According to this theory, there are two distinct conceptual domains of the metaphors; namely, the source domain and the target domain. The source domain (or Vehicle) is different in quality from the target domain (or Topic). The source domain shows metaphor users' literal use of language (in the spoken or written forms; Vehicle), while the target domain (Topic) signifies metaphor users' underlying thoughts or ideas of the metaphors used. Analyzing the connection between these two domains, four steps were applied: (a) naming/labeling, (b) sorting (clarification and elimination), (c) categorization, and (d) analyzing data (Cameron \& Low, 1999). The quantitative analysis was also carried out to support and explain the qualitative analysis (Creswell, 2008).

\subsection{Aim}

To gain more comprehensive insight into the ELT pre-service teachers' beliefs on teaching, the present study aims to investigate the pre-service teachers' metaphors regarding the teaching practice, practicum in terms of teaching practice/practicum; supervisor, mentor, students, lesson plans, material as the basic dynamics of the process.

On this purpose, the following research question was asked

1. How do ELT pre-service teachers use metaphors to describe their beliefs and experience regarding the dynamics of teaching practice?

\subsection{Participants and Research Setting}

Through convenience sampling, which is nonprobability sampling where members of the target population that meet certain practical criteria, such as easy accessibility, geographical proximity, availability at a given time, or the willingness to participate are included for the purpose of the study (Creswell, 2008), 35 pre-service teachers of English Language Teaching Department were involved in the study. There were 9 male and 26 female participants.

The participants of the study were all pre-service teachers attending to the practicum course, which is a compulsory teaching practice of the department, for 14 weeks. At the beginning of the term, they were randomly assigned to the state schools at elementary and secondary education levels. During the practicum, they were required to teach at least $40 \mathrm{~min}$. full time lesson at the schools as well as to observe the mentors' teaching. Also, they had to prepare a lesson plan for each teaching practice and submit the supervisors for the feedback. After they received feedback, they improved their lesson plans and implemented them in the class that mentors determined. The mentors gave feedback for their performances and improvement during the practicum. Besides, they were frequently observed by the supervisor and evaluated on their performance in terms of teaching skills, interaction with the students, use of activities and materials, classroom management and time management.

\subsection{Data Collection \& Analysis}

Metaphorical elicitation task, in which the target word is given and rationale is expected. The participants were asked to complete the stem of (Target word) is ...... because .... In this way, the vehicle and topic domains of the metaphors could be analyzed (Cameron \& Low, 1999). The questionnaire with 6 open-ended questions for each of the dynamics of teaching practice under research focus was given to the participants. The questioned dynamics of teaching practice were teaching practice/practicum; supervisor, mentor, students, lesson plans, material, were determined as a result of related literature review. The questionnaire consisted of six identical prompts for each dynamic as the practicum is like ... because ....; The students is like ... because ...; The supervisor is like ... because ...; The mentor is like ... because ...; The lesson plan is like ... because ...; The material is like ... because .... One example was also given to complete this metaphorical elicitation task. The questionnaire was delivered online through survey monkey to the participants at the end of the practicum course in the spring term.

From 35 participants, a total of 210 metaphors were collected and they were all listed as in the naming/labeling stage as the first phase of data analysis. Then, the data was analyzed in terms of coherency, relevancy and meaningfulness within the framework of conceptual metaphor theory (Eren \& Tekinarslan, 2013; Saban et al, 2007), in the sorting (clarification and elimination) 26 answers were excluded due to lacking, unclear or unrelated metaphor and explanations. Plain descriptions, no metaphor, fuzzy metaphors were omitted. As a result, out of 210 metaphors, 189 metaphor uses were finally analyzed; respectively 34 metaphors produced for the practicum; 33 for mentors; 30 for supervisor; 33 for students; 28 for lesson plan; 31 for materials. At the third phase, categorization in order to determine a reference point for the group of metaphors and validate the analysis and interpretations; the sorted 
metaphors were categorized under one main expression representing all metaphors. In that way, five categories for the practicum metaphors, 4 categories for mentors; 3 categories for supervisors; 3 categories for students; 2 categories for lesson plan and 3 categories for materials were defined. To elucidate the connection between the topic and vehicle and explain the participants' beliefs better in relation with each dynamic. All procedures were conducted with an independent rater to ensure the reliability of data analysis as calculated as 0.90 with Miles and Huberman's (1994) formula. After qualitative analyses, a quantitative analysis was applied and frequencies were calculated to picture the distribution of metaphors under certain categories for each dynamic.

\section{Results}

To investigate the participants' conceptualization of the basic dynamics of the practicum through metaphor analysis, 189 metaphors, remained after the analysis, were examined and categorized to interpret their beliefs accordingly. To picture the general conceptualization of the participants, the descriptive statistics on the distribution of metaphor use and categories are given in Table 1.

Table 1. The summary and distribution of Conceptual Metaphors and Categories

\begin{tabular}{|c|c|c|c|}
\hline Concept & Categories of Metaphors & $\%$ & $F$ \\
\hline \multirow[t]{6}{*}{ PRACTICUM } & Practicum as a performance & 29,41 & 10 \\
\hline & Practicum as a journey & 23,53 & 8 \\
\hline & Practicum as a pitfall & 20,59 & 7 \\
\hline & Practicum as venue & 11,76 & 4 \\
\hline & Practicum as a vagueness & 14,71 & 5 \\
\hline & 34 metaphor & & \\
\hline \multirow[t]{5}{*}{ MENTOR } & Mentor as authority & 39,39 & 13 \\
\hline & Mentor as guide & 30,30 & 10 \\
\hline & Mentor as caring & 18,18 & 6 \\
\hline & Mentor as non-functional & 12,12 & 4 \\
\hline & 33 metaphor & & \\
\hline \multirow[t]{4}{*}{ SUPERVISOR } & Supervisor as authority & 60,00 & 18 \\
\hline & Supervisor as guide/caring & 23,33 & 7 \\
\hline & Supervisor as source & 16,67 & 5 \\
\hline & 30 metaphor & & \\
\hline \multirow[t]{4}{*}{ STUDENTS } & Students as need-care & 54,55 & 18 \\
\hline & Students as out-of-control & 36,36 & 12 \\
\hline & Other & $\mathbf{9 , 0 9}$ & 3 \\
\hline & 33 metaphor & & \\
\hline \multirow[t]{3}{*}{ LESSON PLAN } & Lesson plan as route map & $\mathbf{7 8 , 5 7}$ & 22 \\
\hline & Lesson plan as a torture/redundancy & 21,43 & 6 \\
\hline & 28 metaphor & & \\
\hline \multirow[t]{5}{*}{ MATERIAL } & Material as scaffolding & 58,06 & 18 \\
\hline & Material as uncertainty & 32,26 & 10 \\
\hline & Material as fun & 9,68 & 3 \\
\hline & 31 metaphor & & \\
\hline & TOTAL & & 189 \\
\hline
\end{tabular}

As seen in Table 1, the participants produced the almost same amount of conceptual metaphors regarding the dynamics of the practicum, except lesson plan, which had 28 metaphors. Thus, it could be said that the participants could express their beliefs about the teaching practice, mentors, supervisors, students, and materials effectively with 
diverse metaphors.

To gain insights for each dynamic of practicum, the metaphors and categories for each concept were analyzed and discussed in the following sections.

\subsection{Conceptual Metaphors Regarding Teaching Practice}

Firstly, the participants' beliefs about the teaching practice that they experienced for 14 weeks at state schools during the practicum course were investigated. There were 34 metaphors produced by the participants, these conceptual metaphors were categorized into five in order to discuss the participants' differing beliefs. The categories were labeled as practicum as performance; journey, pitfall, venue and vagueness. The categorization of the metaphors is given in Table 2.

Table 2. Categories and Metaphors regarding Practicum Concept

\begin{tabular}{|c|c|c|}
\hline $\begin{array}{c}\text { PRACTICUMASA } \\
\text { PERFORMANCE }\end{array}$ & $\begin{array}{c}\text { PRACTICUMASA } \\
\text { PITFALL }\end{array}$ & $\begin{array}{c}\text { PRACTICUMASA } \\
\text { VENUE }\end{array}$ \\
\hline Rehearsal $(n=4)$ & Shooting ground $(n=2)$ & Noisy hallway \\
\hline Real world $(n=2)$ & Swimming pool & Kindergarten \\
\hline An arena & Timelessness & A lab \\
\hline A show & Sea & Circus \\
\hline Theatre & A double-edged sword & \\
\hline Training area & Examination & \\
\hline $29,41 \%$ & $20,59 \% \quad n=7$ & $11,76 \% \quad n=4$ \\
\hline PRACTICUM AS A JOURNEY & $\begin{array}{l}\text { PRACTICUM AS } \\
\text { VAGUENESS }\end{array}$ & \\
\hline a journey $(n=2)$ & Dilemma & \\
\hline The preparation before a journey. & newly tasted food & \\
\hline A way with stones & Doubt & \\
\hline A steeplechase & $\begin{array}{l}\text { travelling to an unknown } \\
\text { place }\end{array}$ & \\
\hline $\begin{array}{c}\text { A must straight path } \\
\text { Sea voyage }\end{array}$ & Being a newborn child & \\
\hline $23,53 \%$ & $14,71 \% \quad n=5$ & \\
\hline
\end{tabular}

When the participants' metaphors related with practicum are analyzed, it was observed that the participants mostly saw the practicum as a performance. The most frequently used metaphor under this category was rehearsal as the practice just before the real performance. The other metaphors such as show, theatre and arena could be also connoted with the idea of performing in front of audience. On the other hand, the metaphor of real world was also produced by two participants, which implies that the practicum is an actual performance according to the participants. After the category of performance, the participants described the teaching practice as a journey. The used metaphors such as a way with stones and steeplechase, indicated that some participants were anxious and not sure about their experience. They explained that they had many burdens to overcome and they must go on. Their negative attitudes were also revealed with the metaphors categorized under practicum as pitfall, in which they described their teaching practice as shooting ground, a double-edged sword. For the metaphors of swimming pool and sea it was explained that "we tried to swim although we did not how to do". "I cannot see the end, I just struggle". In addition to such pessimism, some participants were not certain about the nature of practicum and described it as dilemma, doubt and travelling to unknown. Lastly, the participants associated the practicum with different places such as circus, lab, kinder garden and nosy hallway. They tended to resemble their classroom with these places considering their experience.

To sum up, it can be claimed that the participants were critical and reflective about the use of metaphors as they conceptualized their different experience with diverse metaphors. Although they agreed that the practicum was performance just before their profession, still they had some anxieties about this process as explained under the 
category of journey. Additionally, some of them were pessimistic due to the difficulties they experienced during the practicum.

\subsection{Conceptual Metaphors Regarding Mentors and Supervisors}

To picture the participants' beliefs regarding the practicum in more comprehensive way, two main figures, mentors and supervisors were focused in the study. The participants' beliefs were investigated through the conceptual metaphors as categorized under related expressions. The findings are illustrated in Table 3.

Table 3. The Categories and Metaphors Regarding Mentors and Supervisors

\begin{tabular}{|c|c|}
\hline MENTOR AS AUTHORITY & SUPERVISOR AS AUTHORITY \\
\hline Judge $(n=4)$ & Inspector $(\mathrm{n}=3)$ \\
\hline Proctor & Detective $(n=3)$ \\
\hline A dominant Queen & Coach $(n=2)$ \\
\hline Director & Judge \\
\hline An observer & Rule maker \\
\hline Artist & Check-up \\
\hline Raging flame & Observer \\
\hline Body guard & Tailor \\
\hline Boss & God \\
\hline \multirow[t]{3}{*}{ Driver } & Shepherd \\
\hline & Assassin \\
\hline & Eyes \\
\hline MENTOR AS GUIDE & SUPERVISOR AS GUIDE/CARING \\
\hline Light $(n=3)$ & A parent $(n=2)$ \\
\hline Guide $(n=3)$ & An angel \\
\hline Model & Team-Coach $(n=2)$ \\
\hline A Documentary & Corner stone \\
\hline \multicolumn{2}{|l|}{ Sample } \\
\hline \multicolumn{2}{|l|}{ The Mother Bird } \\
\hline MENTOR AS CARING & SUPERVISOR AS SOURCE \\
\hline Angel $(n=4)$ & Guidebook $(\mathrm{n}=2)$ \\
\hline Mother & Coffee \\
\hline Helper & Book \\
\hline \multicolumn{2}{|l|}{ MENTOR AS NON-FUNCTIONAL } \\
\hline Walk-On & \\
\hline Gap & \\
\hline $\begin{array}{c}\text { Uneducated Relative } \\
\text { Television }\end{array}$ & \\
\hline
\end{tabular}

The results as given in Table 3, indicated that the participants used slightly more metaphors regarding the mentors $(n=33)$ than the supervisor $(n=30)$. While there were three categories for the supervisors, the conceptual metaphors on mentors were compiled under four categories. When the distribution and diversity of the metaphors were examined, it was seen that the participants used more distinct metaphors for mentors. In the categorization stage, it was observed that both mentors and supervisors were described as authority and guide with the metaphors. There were two similar metaphors for both mentors and supervisor, which were judge and observer, which refers to the fact that both mentors and supervisors observed their performance and grade them. Although the other metaphors chosen to describe the same conceptualization differed, the explanations were more less the same. For instance; under the category of authority, mentors were described as dominant queen and boss, at the same time, supervisors were perceived as rule maker, and god. They were explained that "whatever they decided was the rule". In addition to the mission of judging, the supervisors were seen as the authority with the metaphors of inspector and detective as inspecting and looking for their weakness and strengths. As one the participants stated that "Supervisors are there to check our capabilities and weaknesses". One interesting metaphor regarding supervisor was produced by one of the 
participants as "supervisors are like an assassin because you will never be sure s/he is coming until it is too late". Although the metaphor seems to have too negative connotation, the explanation implies that the participant wanted to refer to not announced observations of the supervisors, which was also one application of the practicum course. In order to encourage the pre-service teachers to get ready for all lessons, the supervisors do not announce when they will observe their teaching practice.

When the number of metaphors produced for each concept under the category of authority was compared, it was seen that supervisors were perceived more as authority figure than the mentors, however, for the category of guide/caring, mentors were described as light, guide and model that they learned as observing. This result could be interpreted that the participants could benefit from their observation of the mentors in the practicum.

On the other hand, different from supervisors, there were some metaphors with negative connotations that criticizing the mentors such as walk-on and gap. One of the participants described that mentors are like television "I find helpful things (teaching strategies) on her but I often watch unhelpful things and so I feel bored when I was watching her.".

All in all, the results on the conceptual metaphors used to describe the mentor and supervisor indicated that the participants were mostly adopted the authority of mentors and supervisors. They mostly reconciled them with judging, directing, observing and ruling, which are reasonable considering the grading responsibilities of the mentor and supervisors. Nonetheless, they were also described as guide and caring, which helped them during the practicum. The metaphors regarding the mentors under the category of guide implied that they benefited from the observing the mentors and class during the practicum as well. The supervisors were also defined as source as complying with the role of university instructors. Most of the supervisors were the professors who gave the methodology of language teaching courses to the participants so far.

\subsection{Conceptual Metaphors Regarding Students, Lesson Plan and Materials}

The participants' beliefs regarding the concepts of students, lesson plan and materials, which are the essential dynamics of the practicum were also investigated through metaphor analysis, then the conceptual metaphors for each were categorized. The distribution of the metaphors and categories were illustrated as in Table 4.

Table 4. Distribution of Conceptual Metaphors and Categories regarding Students, Lesson Plan and Materials

\begin{tabular}{ccc}
\hline STUDENTS AS NEEDCARE & LESSON PLAN AS ROUTE MAP & MATERIALS AS \\
& & SCAFFOLDING \\
\hline Flowers (n=8) & Map $(\mathrm{n}=12)$ & Savior $(\mathrm{n}=5)$ \\
New born babies $(\mathrm{n}=3)$ & Guidebook $(\mathrm{n}=3)$ & Salt $(\mathrm{n}=3)$ \\
Travelers without a map $(\mathrm{n}=2)$ & Compass $(\mathrm{n}=2)$ & Key $(\mathrm{n}=3)$ \\
Seed $(\mathrm{n}=2)$ & Schedule & Friend $(\mathrm{n}=2)$ \\
Ships in the ocean & Architect table & Leverage (n=2) \\
Robots & Medicine & Diamond \\
Friends & Prospectus & Knives and forks \\
& Holly book & Breathe \\
STUDENTS AS & LESSON PLAN AS A & MATERIAL AS \\
OUT-OF-CONTROL & TORTURE/REDUNDANCY & UNCERTAINITY \\
Monsters (n=4) & Burden (n=2) & Water (n=3) \\
Floating mine (n=2) & Nightmare & Black hole (n=2) \\
Wild animals $(\mathrm{n}=2)$ & Ghost & Fire (n=2) \\
Boiling water $(\mathrm{n}=2)$ & Fire & Shuriken \\
The climate of black sea region & Trivial & Rock \\
Bees & & Moon \\
Other & & MATERIAL AS FUN \\
Sacrificial lamb & & A Toy (N=2) \\
Audience & Amusement park \\
Candle & & \\
\hline
\end{tabular}

The distribution of the metaphors under the referenced categories indicated that the participants used a wide range of 
metaphors to describe the three main concepts; students, lesson plans and materials, which are the basics to perform the teaching practice. Out of these concepts, the participants produced more metaphors $(n=33)$ regarding the students. It shows that they had more experience to express in images. These metaphors were categorized into three groups, the participants used the metaphors more under the category of students as need-care to describe the students who needed their care and attention. The metaphor of flowers was the most frequent, which implies that participants were merciful and positive about the students. They were aware that the students needed their teaching. Some example explanations are as in follows:

The students are like flowers

because each of them requires water(lesson) to grow(graduate)

because they need to be cared of

because as long as you water them, they will blossom.

Because they need something to come into leaf.

As with similar associations, the metaphor of new born babies, as the other frequent one, and seed had the similar explanations. Meanwhile, the metaphor of robots was also used with the explanation that "They are doing as they are programmed". It can be interpreted that the participants felt the control and power, which were perceived as necessity over the students while teaching.

On the other hand, there were some metaphors with negative connotations, categorized under the group of out-of-control. The metaphors under the monitor implied that they had difficulty to manage the students and they were too kinesthetic and sometimes out of control to manage in the class. The metaphor of monsters are a kind of idiomatic expression in the participants' L1 (i.e. Turkish) to define the ones who are so naughty and energetic. Some related explanations are as follows:

They have this limitless energy they want to spend recklessly, and also so much love to give.

You can never know what they will do

The other metaphors such as floating mine, boiling water, bees and the wild animals implied the participants' difficulties in classroom management. The metaphor of the climate of black sea region is also cultural idiom that is used to describe the changing situation, once sunny then rainy. There are three metaphors that could not be categorized under a certain expression but stands as meaningful. They were sacrificial lamb, audience and candle.

Regarding the concept of lesson plan, the metaphors were compiled under two categories. Considering the connotation of the metaphors and categories, it could be said that the participants had two opposing attitudes towards lesson planning. There were more metaphors produced under the category of lesson plan as route map so it can be claimed that participants favored lesson planning. The most frequent metaphor used to describe lesson was map. The participants stated that lesson plan is like a map because

When you go to somewhere or do something you always need a plan

It opens you a route to continue in the lesson.

It shows the way that the lesson should move ahead

It shows the route of the lesson

The other metaphors under this category, namely compass, guide book, schedule and prospectus all indicate that the participants though that lesson plan guided them and they could find whatever they needed in the plan. On the other, some participants preferred the metaphors with negative connotations such as burden, nightmare, ghost. As explained by the participants they had difficulties in lesson planning.

Regarding the last dynamic of the practicum, materials, it was observed that most of the participants used affirmative metaphors, which shows their positive attitude towards the use of materials in the practicum. As the metaphors indicated that they appreciated the materials and they defined them as savior, even they though that without materials, their teaching would be useless, thus they used the metaphor of salt, which was explained as "without it, it would not taste well" and "it's used in almost any dish smartly in order to have a better experience. Yet, it might still go wrong if handled poorly". One of the participants also defined the materials as breath that helped her/him survive. Additionally, the participants defined the material use as fun in the class with the metaphors of toys and amusement park referring the times, they had fun together with the students. The last category related with the concept of materials was determined as materials as uncertainty. The participants produced metaphors of water, black hole and 
fire, which were explained that they were not sure whether the materials would work in the class or not until they used it. In other words, some participants were not sure about the efficiency of materials they found or designed until they used in the class. Related to this, one of the participants used the metaphor of moon, which was explained as "it helps you while giving lesson, but if you don't use it properly. It doesn't work. That is teacher is sun, and material is moon which takes light from the sun".

As the results indicated, each concept was described by distinctly different metaphors although there were similarities among some metaphors regarding different concepts. For example, the metaphor of friend was used to describe the students as the ones need care, then the same metaphor was used to describe material under the category of scaffolding referring the ones that support when needed. The positive connotation of the metaphor showed that the participants preferred this metaphor to express the good attitudes towards the concepts. Furthermore, considering the wide range of metaphor uses for each concept, it can be claimed that the participants could reflect on their experience regarding these practicum dynamics and conceptualize their beliefs through different but meaningful metaphors. Considering the outnumber of the affirmative connotations of metaphors, it could be stated that they had more positive experience in the practicum on these dynamics, yet the metaphors categorized as out-of-control, redundancy and uncertainty implied that they need more time and practice to overcome the difficulties of these dynamics.

\section{Discussion}

Different from other studies on the metaphor analysis of pre-service teachers and their cognition on teaching, the present study adopted a larger perspective and investigated their conceptualization of the dynamics of the practicum, namely teaching practice, mentors, supervisor, students, lesson plan and materials. The overall results indicated that the pre-service teachers could conceptualize their beliefs on teaching practice and related dynamics referring to their experience. In line with their beliefs and attitudes, they chose the metaphors with positive or negative connotations. For instance, some participants were positive about the practicum and defined it with the metaphors referring to performance while some of them described the practicum with a kind of negative metaphors and the emerged categories were pitfall and vagueness. These metaphors revealed that some participants needed more supervision to overcome the problems in the practicum.

In the study, the pre-service teachers' beliefs about the mentors and supervisors were also analyzed. As emphasized in the literature, these two figures are influential on the pre-service teachers' beliefs and thus their teaching performance (Valencic, \& Vogrinc, 2007; Seferoglu, 2006), the results of metaphor analysis indicated that most of the participants agreed on the authority of mentors and supervisors. Considering Eren and Tekinarslan's (2013), the pre-service teachers used cognitive metaphors such as judge, director, observer, queen, rule maker. Seferoglu et al (2009) defined such metaphors under the category of autocratic teacher. These metaphors implied that the pre-service teachers considered the judging, evaluating and grading missions of mentors and supervisors. Different from mentors, more cognitive metaphors describing the supervisors as source were used. Thus, it can be claimed that the participants saw supervisors as expert and the book that they could learn from. In addition to these cognitive metaphors, the participants perceived these two figures as guide and care-giver described with affective metaphors such as guide, parent, angel. It can be interpreted that during the practicum, a rapport with supervisor and mentors were developed and the participants were also aware that these two were there to help them during the practicum process.

To gain insight what they experienced and how they conceptualized their experience, three specific dynamics were included into the analysis; student, lesson and materials. The results indicated that the participants had different experience and attitudes considering the diverse metaphor use for each concept. Particularly regarding the students that they taught in the practicum, they expressed different metaphors with varying connotations. While half of the participants described the students as the ones need care, the rest emphasized how difficult to manage these students. In fact, in compliance with a general view on being a teacher; the one who provides information and takes care of students, the participants agreed that the students are like flowers, which need their teaching, provided information and care. On the other hand, some participants complained about the students referring to their difficulties in classroom management. The problems that the pre-service teachers encounter during the practicum have been emphasized in the literature as well. Complying with Keser \& Yavuz's (2018) conclusion that students were the main source of the classroom management problems of pre-service teachers, the participants of the present study described the students as monster, bees, wild animals which were too noisy and unable to control.

Regarding lesson plan, the participants had two poles aparted; while most of them appreciated the lesson plan as $a$ route map, guide book, compass where to go, what to do and how to teach in the class, some were quite negative towards lesson planning described as torture; burden, nightmare or redundant thing to do. Different from lesson plan, 
there were no negative affective metaphors used for materials. Most of the participants agreed that materials are necessary and beneficial. They preferred the metaphors to emphasize how well-prepared metaphors could scaffold their teaching. These results were complied with Eren and Tekinarslan's (2013) finding that the prospective teachers were positive towards the materials.

\section{Conclusion}

The present study focused on the pre-service teachers' beliefs about the practicum and investigated how they conceptualized the basic dynamics of the practicum through metaphor analysis. The results indicated that the participants could reflect on the practicum process and dynamics with effect of their experience. In other words, the pre-service teachers' beliefs and performances were apt to be influenced with what they experience. While the participants, who had positive experience regarding the target concept, expressed themselves in affirmative metaphors with positive attitude, the negative experience caused pessimistic metaphors and negative attitude. Thus, it could be claimed that the practicum is an important process to shape the pre-service teachers' beliefs and performance. Any bad or negative experience could demotivate the pre-service teachers and caused biased performances in the future. When the pre-service teachers' beliefs and attitudes towards the practicum process and its related dynamics are examined frequently, the problematic areas could be detected and supervision or improvisations could be offered to overcome any problems. In the further studies, the reasons of these negative metaphors and attitudes could be investigated more through interviews and class-observations could be conducted to detect the discouraging or problematic teaching experience.

\section{References}

Borg, M. (2005). A case study of the development in pedagogic thinking of a pre-service teacher. TESL-EJ, 9(2), $1-29$

Borg, S. (2003). Teacher cognition in language teaching: A review of research on what language teachers think, know, believe, and do. Language Teaching, 36(2), 81-109. https://doi.org/10.1017/S0261444803001903

Cabaroglu, N. \& Roberts, J. (2000). Development in student teachers' pre-existing beliefs during a 1-year PGCE program. System, 28(3), 387-402.https://doi.org/10.1016/S0346-251X(00)00019-1

Carter, K. (1990). Meaning and metaphor: Case knowledge in teaching. Theory into Practice, 29(2), 109-15.https://doi.org/10.1080/00405849009543440

Casebeer, D. (2015). Mapping preservice teachers' metaphors of teaching and learning. International Journal of Learning, Teaching and Educational Research, 12(3), 13-23

Clandinin, D. J. (1986). Classroom practice: Teacher images in action. London: Falmer Press.

Collins, E.C. \& Green, J. L. (1990). Metaphors: The construction of a perspective. Theory into Practice, 29(2), 71-7https://doi.org/10.1080/00405849009543435

Collinson, V. Kozina, E., Lin, Y. K., Ling, L. Matheson, I. Newcombe, L. \& Zogla, I (2009). Professional development for teachers: a world of change. European Journal of Teacher Education, 32(1), 3-19.https://doi.org/10.1080/02619760802553022

Cameron, L. \& Low, G. (1999). Metaphor. Language Teaching, 32(2), 77-96. http://dx.doi.org/10.1017/S0261444800013781

Creswell, J. W. (2008). Research design: Qualitative, quantitative, and mixed methods approaches. London: Sage Publications.

Farrell, T.S.C. (2006). The teacher is an octopus: Uncovering preservice English language teachers' prior belief through metaphor analysis. RELC Journal, 37(2), 236-48.https://doi.org/10.1177/0033688206067430

İnceçay, V. (2015). The Foreign Language Classroom is Like an Airplane Metaphorical Conceptualizations of Teachers' Beliefs. Turkish Online Journal of Qualitative Inquiry, 6(2), 74-96https://doi.org/10.17569/tojqi.48011

Johnston, S. (1994). Experience is the best teacher; or is it? an analysis of the role of experience in learning to teach. Journal of Teacher Education, 45(3).https://doi.org/10.1177/0022487194045003006

Kavanoz, S. (2016). Unveiling Pre-service Language Teachers" Conceptualizations of Teachers of English through Metaphors. Journal of Education and Training Studies, 4(10), 18-32. https://doi.org/10.11114/jets.v4i10.1690

Karagöz, T., Şükür M. \& Filiz, S. (2019). Pre-servıce EFL teachers' metaphorıcal conceptualızatıons of an EFL 
teacher. European Journal of English Language Teaching, 3(3), 44-57. doi: 10.5281/zenodo.1173777

Kramsch, C. (2003). Metaphor and the subjective construction of beliefs. In: Kalaja, P. \& Barcelos, A. M. F. (Eds.). Beliefs about SLA: New research approaches. Dordrecht: Kluwer Academic Publishers.https://doi.org/10.1007/978-1-4020-4751-0_5

Keser, K. \& Yavuz, F. (2018). Classroom management problems pre-service teachers encounter in ELT. Cypriot. Journal of Educational Science, 13(4), 511-520. https://doi.org/10.18844/cjes.v13i4.3184

Lakoff, G. \& Johnson, M. (1980). Metaphors we live by, Chicago: University of Chicago Press

Lortie, D. (1975). Schoolteacher: A sociological study. Chicago: University of Chicago Press.

Mattheoudakis, M. (2007) Tracking changes in pre-service EFL teacher beliefs in Greece: A longitudinal study. Teaching and Teacher Education, 23, 1272-1288.https://doi.org/10.1016/j.tate.2006.06.001

Miles, M, B. \& Huberman, A. M. (1994). Qualitative data analysis: An expanded Sourcebook. (2nd ed). Thousand Oaks, CA: Sage.

Nagamine, T. (2012). A metaphor analysis of preservice EFL teachers' beliefs regarding professional identity. Asian EFL Journal, 14(2), 141-171

Othman, J. \& Kiely, R. (2016). Pre-service teachers' beliefs and practices in teaching English to young learners. Indonesian Journal of Applied Linguistics, 6(1), 50-59https://doi.org/10.17509/ijal.v6i1.2661

Oxford, R., Tomlinson, S., Barcelos, A., Harrington, C., Lavine, R. Z., Saleh, A. \& Longhini, A. (1998). Clashing metaphors about classroom teachers: Toward a systematic typology for the language teaching field. System, 26(1), 3-50. https://doi.org/10.1016/S0346-251X(97)00071-7

Pajares, M. F. (1992). Teachers' beliefs and educational research: Cleaning up a messy construct. Review of Educational Research, 62, 307-332. https://doi.org/10.3102/00346543062003307

Peacock, M. (2001). Pre-service ESL teachers' beliefs about second language learning: a longitudinal study. System, 29, 177-195.https://doi.org/10.1016/S0346-251X(01)00010-0

Richardson, V. (2003). Preservice Teachers' Beliefs. In J. Raths \& A. R. McAninch (Eds.), Teacher Beliefs and Classroom Performance: The Impact of Teacher Education, 1-22. Greenwich, CT: Information Age Publishing.

Tobin, K. (1990). Changing metaphors and beliefs: A master switch for teaching? Theory into Practice, 29(2), 122-7.https://doi.org/10.1080/00405849009543442

Saban, A. (2006). Functions of Metaphor in Teaching and Teacher Education: A review essay. Teaching Education, 17(4), 299-315https://doi.org/10.1080/10476210601017386

Saban, A. (2010). Prospective teachers" metaphorical conceptualizations of learner. Teaching and Teacher Education, 26, 290-305.https://doi.org/10.1016/j.tate.2009.03.017

Seferoğlu, G. (2006). Teacher candidates' reflections on some components of a preservice English teacher education programme in Turkey. Journal of Education for Teaching, 32(4), 369-378.https://doi.org/10.1080/02607470600981953

Seferoglu, G., Korkmazgil, S. \& Ölçü, Z. (2009). Gaining insights into teachers' ways of thinking via metaphors. Educational Studies, 35(3), 323-335https://doi.org/10.1080/03055690802648135

Şimşek, M. (2014). Examining preservice teachers' conceptions of language and the development of their teaching beliefs over the practicum. Procedia-Social and Behavioral Sciences, 152, 937-942. https://doi.org/10.1016/j.sbspro.2014.09.346

Suárez Flórez, S. A. \& Basto Basto, E. A. (2017). Identifying pre-service teachers' beliefs about teaching EFL and their potential changes. PROFILE Issues in Teachers' Professional Development, 19(2), 167-184.https://doi.org/10.15446/profile.v19n2.59675

Yuan, R. \& Lee, I. (2014). Pre-service teachers' changing beliefs in the teaching practicum: Three cases in an EFL context. System, 44, 1-12.https://doi.org/10.1016/j.system.2014.02.002

Valencic, M. \& Vogrinc, J. (2007). A mentor's aid in developing the competences of teacher trainees. Educational Studies, 33(4), 373-384.https://doi.org/10.1080/03055690701423473

Wan, W., Low, G.D. \& Li, M. (2011). From students' and teachers' perspectives: Metaphor analysis of beliefs about EFL teachers' roles. System, 39(3), 403-415.https://doi.org/10.1016/j.system.2011.07.012 